Let us take one long step in time from I865 to r9or, and note a few of the leading points concerning plants that are now demanding the attention of students. New worlds have been discovered and each is now well taught in many colleges. I mentioned three above. We have them still, with additions, and five at least have been added, viz.: Plant histology, plant physiology, ecology, bacteriology, parasitic fungi and saprophytic fungi. Through the rapid development of agricultural colleges and work in the United States Department of Agriculture, opportunity was offered to earn money by a knowledge of plants. The universities soon gave a greater opportunity to elect botany than ever before. Today I dare not attempt to name or enumerate the hundreds of persons in this country, all of whom get their living by work with plants. Progress in every line is most marked, as we might expect where so many well-trained enthusiasts are occupying so many different fields. Botarıy in any of its departemnts is a charming and valuable study for pleasure, information, discipline or culture.

The older botanists of today have been obliged to bestir themselves continually to keep atreast of the times. They consult each other by letter, in person, or meet in conventions. They visit a number of the best equipped laboratories of this country or of Europe and remain as students or remain long enough to secure many hints that will be of value in wcrk with their own classes. Without this, they would soon be shelved, or teach the old botany with none of the new.

\title{
THE HIGH SCHOOL LIBRARY FOR CHEMISTRY.
}

J. BISHOP TINGLE, PH. D.

Professor of Chemistry, Illinois College, Jacksonville, Ill.

Most teachers will probably agree that the provision of a library for the Chemical Departments of secondary schools is almost as essential to their complete efficiency as, say, an adequate supply of test tubes and flasks; yet it undoubtedly happens that, 


\section{Icbool Icience}

in too many schools, the library is either totally lacking or wholly insufficient. I desire to call attention to this need, and, if possible, strengthen any efforts to meet it, because experience has shown me that the possession of a library will be speedily attended by beneficial results, both to the teachers themselves and to their students.

For several years it has been my privilege to interview students, with some chemistry credits, coming from other institutions, and to the question, "What work have you done on the subject?" I have frequently been told, "Oh! I have done a great deal of chemistry. I have had a year of $i t$ "; or, "I have done the whole of chemistry; we studied it two hours weekly during six months." The italics are the student's. Obviously an individual entertaining such quaint ideas must first have impressed on him certain of the more elementary truths of perspective, and be brought to a truer realization of the actual relationship of his ego to the cosmos. The operation is usually rather painful to the student, somewhat of a bore to the teacher, and involves an expenditure of time that might be better employed.

Again, it is frequently found that an inaccurate statement or definition 1 s regarded as beyond question "because So-and-so says it," So-and-so being the author of the text-book in use. The ideal text-book remains to be written, few of the available ones are without error, all have some blemish, and it appears that the teachers' efforts to correct them often had the effect of impressing the inaccuracies on the mind of the student with special force. A well-selected library materially helps towards the elimination of both these troubles; its use broadens the student's outlook as to the extent of the subject, and enables him to collate various accounts of any part of it. This often has the further great advantage of enabling him to grasp some special point, as put by $B$, that he may have vainly struggled with in A's book. In addition it begets in him the habit of reference, which must be of considerable value in subsequent work, and reading somewhat away from the routine lines will open up new paths of interest and extend old ones.

The chief advantages to the teacher of a library are perhaps two: access to reliable books of reference, and means of keeping 
abreast of new work, including not merely the results of research as ustually understood, but also improvements in lecture and class experiments, novel equipment, etc. Should the teacher be compelled to purchase his own works of reference, a somewhat heavy and rather inequitable tax is imposed on salaries usually far from liberal.

As regards the second point, many teachers are from their location necessarily deprived of ready access to current technical periodicals and books, and even if the works are available, the large amount of time required merely to "skim" them is a serious matter, whilst the rapid advancement of knowledge and the resulting luxuriant development of novel terminology, renders it difficult for any but specialists in various branches of the science to recognize the relative importance of new work and assess it at its approximate value.

\section{THE STUDY OF BACTERIA IN THE PUBLIC SCHOOLS.}

BY JAMES E. PEABODY.

Instruetor in Biology, Peter Cooper High school, $N, Y$.

The highest aims in "municipal housekeeping" can never be attained by Boards of Health or by Departments of Street Cleaning alone, however efficient these organizations may be. Unnless these city departments are backed by a strong, intelligent public sentiment we shall experience nothing better than sporadic reform in the cleaning of our streets, in the construction of tenement houses, and in the general care for the public health. When conditions get sufficiently bad in a community, it is comparatively easy to arouse the voters and roll in a reform administration by big majorities. But alas! we soon tire of our attempts at public virtue, we reverse our votes at the next election, and sink back into easy toleration of filth and its resulting disease. One might indeed become pessimistic with reference to the future of our cities were it not true that democracy possesses a most powerful means of developing a public sentiment which may be at once intelligent and lasting. Gathered in our schools of today are the 